\title{
Mind Mapping: Learning strategy for novice learners of anatomy for physical education undergraduate program
}

\author{
Agam Akhmad Syaukani ${ }^{1}$, Lutfi Abdil Khuddus ${ }^{2}$, Nur Subekti ${ }^{3}$ \\ \{aas622@ums.ac.id 1 lut.fikunesa@gmail.com ${ }^{2}, \underline{\text { ns584@ums.ac.id }}{ }^{3}$ \}
}

Universitas Muhammadiyah Surakarta ${ }^{1}$,Shanghai University of Sport ${ }^{2}$

\begin{abstract}
There is an important demand for faculty in undergraduate program to deliver lecture through student-centered learning environment. The purpose of this study is to determine the effects of a mind -mapping learning strategy on novice learner's basic knowledge of anatomy. The subject of this study were new entrants of physical education undergraduate program of Universitas Muhammadiyah Surakarta. A paper-based mindmap learning strategy was introduced to the students in the experimental group to improve their basic knowledge of anatomy. This study applied the experimental method using control group design. Through one-way ANOVA analysis, it was found that paperbased mind-map learning strategy had no significant contribution enhancing basic understanding of anatomy in the experimental group. In addition, the results of simple paired t-test analysis indicated that mind-map performed as similar to standard note taking technique as an effective method to facilitate students learning new subject.
\end{abstract}

Keywords: mind map, student-centered learning, critical thinking, creativity

\section{Introduction}

Physical education (PE) undergraduate program often recruit highschool graduate from major other than science. Thus bringing their first year in college difficult to get maximum result in science-related subjects as they have no background in science and medical subject which become part of the curricullum in PE undergraduate program. Among science related subjects, Anatomy become first subject to be thaught in firs year. The idea of Anatomy for physical education is that PE professionals must effectively and efficiently integrate knowledge of human body structure to design physical activity suitable for students. Human body structure are taught in anatomy subject. Therefore make the subject important for PE students in college.

Lack of basic science knwoledge for PE students make it hard to design a teaching method that compatible to novice learners. It is known that making student embrace the positive classroom experience is a hard task for lecturer. Costumized learning approach is necessary to fulfill the college student's demands for worthy and satisfying calssroom experience in today's educational settings [1]. On this disruptive era, where everything is changed, students need to customize their style of learning. They need to move away from traditional learning where teacher is the center of knowledge in class. Students required the thinking skills that can benefit them finish their task and answer the challenge coming in the globalization era. They are meant to be a problem solver for one problem to another. Research 
indicated that acquiring critical thinking and creativity could help them improve their problem solving abilities [2]. Mind mapping, an active learning method seen to be benefit for students in nursing and medical department to learn science [3][4][5][6][7], it facilitate a studentcentered active learning and promotes the mind's natural ability to think and recall conceptual information in a more effective way [8]. Mind map also accommodate critical thinking and creativity needed to improve problem solving abilities as suggested by Muglia et al [2].

Science education including learning Anatomy needs students to be an active participants. Applying the active learning approach, science education facilitate students in searching, implementation, investigation, experimentation or observation [9]. Faculty members is suppose to swift their teaching methods away from teacher-centered educational approaches and actualize an active student-centered learning situation. Moreover, through the class, teacher need to develop their students' critical thinking. Hence make them think everything in the most efficient way [2]. Current studies suggested that developing students' critical thinking could eventually improve their academic performance. Despite its academic relevance, especially in university, critical thinking is useful to produce plan, organize, supervise, and, measure academic tests which directed beyond the classroom and into students' personal and social lives [10].

Linear teaching method such as the use of outlines, and traditional note taking are still dominant as the attributes to standard teaching. Although these techniques are helpful, the methods discourage students to have engangement in class, associations, and creativity [11]. Buzan [8] introduced a learning method that could promotes radiant thinking that help students engage with their class. The theory of radiant thinking promotes diverse aspects of the brain working in synergy, a natural process, with thought starting from a central point. The mind-mapping technique facilitates the use of our natural ability to think in a radiant manner [8]. Mind mapping has been claimed to help student improve academic performance especially in science [12][4][13][14][15]. To the date, regarding on mind map implementation, there are no study dealing with student without background knowledge in science such as new entrants of undergraduate physycal education program. Therefore, this study aims to investigate the effectiveness of mind map as a learning strategy for first-year student of PE undergraduate program in Anatomy subject.

\section{Method}

\subsection{Study design}

This is a comparative study of the effectiveness of using mind mapping (MMP) as learning strategy versus standart note taking (SNT). SNT is describe as any study approach that does not include reorganizing information using special form as can be observed in a concept map or mind map[16]. SNT is process whereby notes are compiled in a hierarchy from the top of the page to the bottom, or from left to right without any hierarchy[15]. This study design as quasi experiment with control group and experimental group. This study explores the relationship between : 1) Mind mapping (MMP) and students' achievement in Anatomy tests; 2) Standard note taking (SNT) and students's achievement in Anatomy test. 


\subsection{Subjects and intervention}

The subjects consisted of male and female students. The subjects are new entrants undergraduate student majoring in physical education. Subjects is member of anatomy class. A total of 88 students were recruited in this study. Students were randomly assigned to equal group namely control and experimental group. In addition to the mix abilities in groups, lecturers were also asked to ensure that the groups were mixed in gender. Subjects were given an Anatomy lesson for 11 weeks (one session last for 3 hours per week). During the 12th week, subject were asked to recall the conceptual knowledge already given in class using MMP (experimental group) and SNT (control group). Prior to mind mapping, experimental group were given explanation about creating mind map and utilize mind map to summarize learning materials. Mind map lesson refered to a prominent mind map website[17] and based on mind map theory developed by Buzan [8].

Students completing the 12th week class session were asked to summarize Anatomy lesson using MMP or SNT respective to their group. Students were given 30 days to prepare themselves for formative asessment to measure their depth of knowledge in Anatomy course. Formative asesssment was implemented by the reseracher using short essay question. In the completion of the research session, a self-administered questionnaire were given to experimental group to obtained their perception regarding mind map. Statistical method of ANOVA and t-test were used to analyze significance difference between two groups.

\section{Result}

The statistical result identified that experimental group obtained an average mark of 86.36 $(\mathrm{SD}=12.45)$ and control group obtained an average mark of $80.73(\mathrm{SD}=17.32)$ during the final test. Statistical analysis found that sig. .092>0.05 therefore there is no significant difference between the two groups.

Table 1. Overview of the participants across condition

\begin{tabular}{|c|c|c|c|c|c|c|}
\hline Group & $\mathbf{n}$ & $\mathbf{M}$ & Sd & Min & Max & Sig. \\
\hline MMP & 39 & 86.36 & 12.45 & 54 & 98 & .092 \\
\hline SNT & 49 & 80.73 & 17.32 & 24 & 100 & \\
\hline
\end{tabular}

However majority subjects $(80 \%, \mathrm{~N}=39)$ in the mind map group have argued that it is a good way to learning Anatomy that it is a useful way of memorizing information. Majority subjects also feel that mind map is a fun and interesting learning method $(90 \%, \mathrm{~N}=39)$. This is similar to other study which also demonstrated students' perceptions that mind map is interesting and fun[18].

\section{Discussion}

The difference in mean score of the test between subjects in the SNT group and MMP group was not significant. This finding suggests that both groups exhibited the same information based upon 11-weeks exposure of Anatomy. Nevertheless, the students of the experimental group as well as the control group were able to obtain a satisfactory performance level after being exposed to a totally unfamiliar topic. A majority of mind map group had grasped the concept and implementation of mind map in their daily course after initial 
training. A majority of them used color and picture to costumize their mind map. The information in the mind map was varied among students in the experimental group reflecting their personal educational needs.

The final test was given to subjects after the respective subjects were exposed either with MMP or SNT for 6 weeks. Although the mean score of the final test was slightly higher among subjects in the MMP $(86.36, \mathrm{SD}=12.45)$ compared to those in the SNT group (80.73, $\mathrm{SD}=17.32$ ), the difference was not significant. The result suggest that mind mapping is not superior to standard note-taking for basic Anatomy lesson. Similar results were also found in others study(Antoni, Zipp, Olson, \& Cahill, 2010; Wickramasinghe et al., 2011). However, it is important that subjects in MMP group did not have score less than those in SNT groups despite that they only receive a brief period of introduction on mind map without further practice to improve their profeciency in mind map.

Buzan and Buzan [8] identified that mind mapping promotes the use of radiant or central thinking to enhance the multiplicity of the brain. Mind mapping facilitates the students explore the concept and its key associations in an organized, colorful, vibrant, and logical manner. When applying mind map in their course, students found themselves attracted to the method. The fact that no significant difference was found between groups may lend support to SNT as a traditional method that has been part of their previous educational background. Familiarization of a certain learning method maybe useful to student to optimize their learning. The subjects in MMP groups may have been distracted to learned something through writing notes in a completely new way. Especially when Anatomy is a new subject for them where learn something new required consistency and determination. Any distraction may have decreased their performance.

\subsection{Limitations and future research}

The mind map introductory for experimental group was time limited. By the end of the session most of the student in the experimental group still not finished their mind map project durig the class. Then reseracher ask them to take it as a homework without supervision. A potential time limitation may reduce their understanding regarding application of mind map. Following the mind map session, students were given the freedom to study their mind map prior the test. The process went without supervision. It was likely unknown wheter during their free time they review their mind map or not.

Because critical thinking required long time to develop, short-term alterations in critical thinking was another limitation of the present study. Numerous mind-map sessions may be important for students to improve proficiency in the strategy before major changes in the acquisition of critical thinking occur [9]. Product quality of mind map from the subject was not being measured. Product quality of mind map refer to mind map depth. As other studies suggested mind map depth increases as students gain proficiency in their construction over time[7].

Future studies should accommodate mind map session in more than once to allow subjects create multiple mind maps so they can gain proficiency in the technique. This would benefit them in order to become expert regarding on mind map creation and develop their critical thinking skill. 


\section{Conclusion}

The data obtained from this study does not support any superiority of mind mapping (MMP) over standard note taking (SNT). Eventhough mean score of MMP group is higher than SNT group, they are not statistically significant. However this findings do not reject the usefulness of mind mapping as a learning strategy as the subjects' product quality of the mind map still not being considered. In order to fully address if mind mapping is effective in organizing, prioritizing and integrating material which foster the development of critical thinking skills, length of mind map exposure should be added with two or more session. To fully understand the changes effect of different learning methods, pre/post test should be implemented during study. In addition, the use of standardized critical thinking assessment tools such as pre post measure on the Health Sciences Reasoning Test (HSRT) also necessary

\section{Acknowledgement}

The authors wish to thank member of Anatomy class of Sports Education major batch ' 18 for their willingness to be part of this study.

\section{References}

[1] Gillies, R. M., \& Haynes, M. (2011). Increasing explanatory behaviour, problem solving, and reasoning within classes using cooperative group work. Instructional Science, 39(3), 349366. https://doi.org/10.1007/s11251-010-9130-9

[2] Muglia, S., Saiz, C., Rivas, S. F., Maria, C., Vendramini, M., Almeida, L. S., ... Franco, A. (2018). Creative and critical thinking: Independent or overlapping components ? Thinking Skills and Creativity, 27(November 2017), 114-122. https://doi.org/10.1016/j.tsc.2017.12.003

[3] Jones, B. D., Ruff, C., \& Snyder, J. D. (2012). The Effects of Mind Mapping Activities on Students ' Motivation The Effects of Mind Mapping Activities on Students ' Motivation. International Journal for the Scholarship of Teaching and Learning, 6(1), 1-21.

[4] Kotcherlakota, S., \& Zimmerman, L. (2013). Developing Scholarly Thinking Using Mind Maps in Graduate Nursing Education. Nurse Educator, 38(6), 252-255. https://doi.org/10.1097/01.NNE.0000435264.15495.51

[5] Rosciano, A. (2015). The effectiveness of mind mapping as an active learning strategy among associate degree nursing students. Teaching and Learning in Nursing, 10(2), 93-99. https://doi.org/10.1016/j.teln.2015.01.003

[6] Wickramasinghe, A., Karunathilake, I., Widanapathirana, N., Kuruppu, O., \& Liyanage, I. (2011). Effectiveness of mind maps as a learning tool for medical students. South East Asian Journal of Medical Education, 30-32.

[7] Zipp, G. P., Maher, C., \& V.D’Antoni, A. (2009). Mind Maps : Useful Schematic Tool For Organizing And Integrating Concepts. Journal of College Teaching and Learning, 6(2), 59-68. 
[8] Buzan, T., \& Buzan, B. (1993). The Mind Map Book How to Use Radiant Thinking to Maximise Your Brain's Untapped Potential. New York: Plume.

[9] Fun, C. S., \& Maskat, N. (2010). Teacher-Centered Mind Mapping vs Student-Centered Mind Mapping in the Teaching of Accounting at Pre-U Level - An Action. In Procedia Social and Behavioural Sciences (Vol. 7, pp. 240-246). https://doi.org/10.1016/j.sbspro.2010.10.034

[10] Phan, H. P. (2010). Critical thinking as a self-regulatory process component in teaching and learning. Psicothema, 22(2), 284-292.

[11] Spencer, J. R., Anderson, K. M., \& Ellis, K. K. (2013). Radiant Thinking and the Use of the Mind Map in Nurse Practitioner Education. Journal of Nursing Education, 52(5), 291-293. https://doi.org/10.3928/01484834-20130328-03

[12] Imaduddin Chomsi, M., \& Nur Utomo, U. H. (2012). Efektifitas Metode Mind Mapping Untuk Meningkatkan Prestasi Belajar Fisika Pada Siswa Kelas VIII. Humanitas, 9(1), 62-75.

[13] Merchie, E., \& Keer, H. Van. (2012). Spontaneous Mind Map use and learning from texts: The role of instruction and student characteristics. Procedia - Social and Behavioral Sciences, 69(Iceepsy), 1387-1394. https://doi.org/10.1016/j.sbspro.2012.12.077

[14] Zipp, G. P., Maher, C., \& Antoni, A. V. D. (2015). Mind Mapping: Teaching and Learning Strategy for Physical Therapy Curricula. Journal of Physical Therapy Education, 29(1), 43-48.

[15] Antoni, A. V. D., Zipp, G. P., Olson, V. G., \& Cahill, T. F. (2010). Does the mind map learning strategy facilitate information retrieval and critical thinking in medical students? BMC Medical Education, 10(1), 61.

[16] Farrand, P., Hussain, F., \& Hennessy, E. (2002). The efficacy of the ' mind map ' study technique. Medical Education, 36(5), 426-431.

[17] Ayoa. (2019). How to Mind Map. Retrieved June 20, 2019, from https://www.ayoa.com/how-to-mind-map/?utm_medium=301\&utm_source=imindmap.com

[18] Syahrir, \& Heliati, E. (2017). Analisis Mind Map Siswa Kelas VII C SMPN Konang. Jurnal Ilmiah Mandala Education, 3(1), 421-434. 